\title{
Study on Influence of WeChat Moments in University Students' Ideological and Political Education and Strategies
}

\author{
Yingnan Zhang ${ }^{1, a}$ \\ ${ }^{1}$ College of Pharmacy, Beihua University, 132013, Jilin City, China \\ ayingnan_zhang@126.com
}

Keywords: Wechat Moments, messaging contact platform, ideological and political education.

\begin{abstract}
Wechat Moments is the most beloved instant messaging contact platform, boasts 600 million loyal users. Moments 1ike a higher degree of privacy, fast information dissemination speed, rich information content as well as an attractive presentation layout all contribute to its popularity among university students and exert a profound influence on their life style. In this paper presents the general view of Wechat is presented to university students' ideological and political education. The paper also puts forward corresponding strategies in order to keep pace with current situations and maximize its advantages.
\end{abstract}

\section{Introduction}

WeChat circle of friends as a new social platform, students play a pivotal position in life, whether in the classroom, the bedroom or the library, whether it is dinner, class or break, you can see the students Holding a mobile phone "brush" circle of friends, they share their own feelings of experience, Tucao their unhappy mood, forwarding interesting or meaningful articles, access to a variety of knowledge. "Praise", "forward", "vote", "comments" and other words these words become college students are chatting everyday language. As the WeChat official website as propaganda: micro letter is a way of life, it is in the Changing our lives. Micro-letter circle of friends in the daily life of the great impact on college students, what is reflected in the face of the new situation, relying on this popular social network of friends, college students ideological and political education and how to go Creative development, is the significance of this study.

First of all, micro-circle is friends and the formation of its popular circle of friends, a profound impact on college students' lifestyles, ideological trends and moral values. The contemporary college students have a keen thinking ability and a strong ability to accept new things. The circle of friends has a positive effect on promoting socialization, interpersonal communication, personality improvement, information acquisition and other aspects of college students. However, undergraduates with poor self-control ability and poor recognition ability will inevitably be affected by the unhealthy atmosphere and information when they are confronted with the mixed information circle of friends. For college students who are in the critical period of shaping the world outlook, outlook on life and values, Is undoubtedly a great threat. Explore how to guide students to correctly view the circle of friends, rational integration into the circle of friends, so that this way of life to become a better way to promote the healthy growth of college students, with strong practical significance.

Second, "education should be oriented to modernization, the world, facing the future", since the WeChat circle of friends for college students have such a great impact, we can not ignore it ideological and political education workers, but should follow the development of the times, full attention in the emerging A Study of the Problems in the Cultural Background of Micro-Friend Circle. The rise of WeChat circle of friends in the group of college students, to the ideological and political education work opportunities also brought challenges. In this paper, we will separate micro-faith circle of friends, combined with communication, sociology and psychological knowledge, analysis and discussion in WeChat circle of friends, cultural background, how to use WeChat circle of friends, innovative ways of ideological and political education, enrich the ideological and political The new 
content of education, better carry out the work of ideological and political education, both theoretical and practical significance.

\section{WeChat circle of friends}

Micro-friend circle refers to a social function on the Tencent micro-letter, in the WeChat version 4.0 April 19, 2012 update on-line, the user can publish text and pictures through the circle of friends, but also through other software to share the article or music to friends ring. Users can be friends of new photos to "comment" or "praise", the user can only see the same friends comments or praise. From this definition can be seen, WeChat circle of friends is the main function of social, the performance of its content and forms are more varied, text, pictures, music, video, etc., can give users a visual audio-visual experience. At the same time can also be seen, WeChat circle of friends is a more private circle, the user can only see a common friend's comments or praise.

Users can press the circle of friends by the camera icon into the release text message interface; the text version of the previous version of the text message does not limit the number of words, but the latest WeChat version of the text word limit of 650 words or less. Text can not be reproduced and reproduced. Users can take pictures or choose photos from the phone albums to the circle of friends, send up to 9 photos at a time, at the same time can be accompanied by text messages. WeChat circle of friends can choose to publish content, choose to shoot up to 8 seconds of small video sharing. Small video can record sound, but does not support forwarding and favorites. Friend Circle supports articles, messages, music, videos, etc. that users share with other applications or micro-commons. Share the content to the form of web links to publish, friends can view, comment and reprint.

January 25, 2015, called "WeChat team" official account in the WeChat circle of friends to promote the "Vivo", "Coca-Cola" and "BMW" three advertising messages; this is the first WeChat circle of friends officially released ads. WeChat circle of friends can be free to share comments and praise, but only between mutual friends can only return to each other and interact. Original photos and text, etc. can not be reproduced, from other applications or micro letter to share the public can be reproduced and collection.

\section{The Influence of Micro - letter Circles on College Students}

In order to better study the WeChat circle of friends culture impact on college students, the author conducted a questionnaire survey and interviews with the form of data collection. The subjects of the questionnaire were full-time undergraduates from freshman year to junior middle school of Huazhong Normal University, and they both opened and used micro letter. A total of 300 questionnaires were distributed, 100 copies were issued for each grade, and $2 \%$ of the valid questionnaires were retrieved. The effective questionnaire recovery rate was $98.7 \%$. The questionnaire mainly involves three aspects: First, it is the basic situation of college students to use WeChat circle of friends, including the micro-information circle of friends to see and use frequency, friends circle structure of friends and so on. Second, students use WeChat circle of friends when interacting with friends, including access to information through the circle of friends, release status, point praise, comments and so on. Finally, is the use of college students and WeChat circling of friends some of the views of the phenomenon, such as marketing, purchasing behavior and other attitudes. In order to ensure the reliability of the survey, the author as a work in the ideological and political education of front-line counselors, but also used the interview method, the ten students conducted in-depth interviews with the results of the questionnaire combined to ensure that the survey results of the reliability and representativeness. 


\section{The WeChat circle of friends brings the opportunity and challenge to the ideological and political education of college students}

WeChat circle of friends to college students' life, learning and growth have brought great impact. On the one hand, the circle of micro-friends provides a comprehensive platform for college students to acquire information and express themselves, and on the other hand, it also has some negative effects on the healthy growth of college students. As an ideological and political education for college students, in the face of this new situation, we can not ignore the influence and significance of WeChat circle of friends for the ideological and political education work of college students. We must face the WeChat circle of friends to the profound impact of college students, but also take the initiative to analyze the WeChat circle of friends to the current ideological and political education work which brought new changes, which raised the problems and challenges for better development of college students Ideological and political education work laid a good foundation.

Ideological and political education is a kind of humanistic education, which is full of life experience, life concern, life meaning and vitality. The CPC Central Committee and State Council "on further strengthening and improving the ideological and political education of the views" also clearly stated that "adhere to the people-oriented, close to the actual close to the students close to the students, and strive to improve ideological and political education pertinence, practical and attractive appeal, Intellectual and aesthetic development of the socialist qualified builders and reliable successors."Thus, the ideological and political education of college students is an inevitable trend of ideological and political education. With the rise of WeChat circle of friends in college students, brush circle of friends has become a way of life of college students, WeChat circle of friends in college life so widely used for ideological and political education work into the life of college students an opportunity. Educators can push the students through the circle of education with educational graphics, or ideological and political education and life practice, combined with practical information to the students recommended close to life, such a recessive ideological and political education broke through the time and space constraints, Into the daily life of college students to college students are more familiar and like the way into the field of vision of college students, compared with the traditional pure theory of education easier to understand and accept the students. Undergraduates like to share their life experience in micro-circle of friends, but it is these daily life bit by bit reflects the students' ideological dynamics and personality traits, the educator can observe and analyze the targeted development of college students thought Political Education Work to Improve the Effectiveness of College Students' Ideological and Political Education.

The content of ideological and political education is multifaceted, Chen Wanbai and others believe that the content of ideological and political education, including the world view of education, political education, outlook on life education, legal education and moral education. But in practical work, some of the educators presented to the students are mostly political and moral aspects, and the content of the theory of strong, more monotonous and one-sided. As a platform for information sharing, micro-credit circle of friends circulates vast amounts of information every day, which also includes various aspects of ideological and political education, to a large extent make up for the traditional ideological and political education of the content of the single and inadequate, enriched the content of ideological and political education of college students. WeChat circle of friends in a lot of media, such as surging network, every day will give users push news hot spots, as well as some social phenomena and events comments and analysis, the views are generally very deep, with a strong guiding role. These social problems and events for the analysis of ideological and political education for students to provide fresh materials, help guide students to form a correct understanding, but also can improve the ability of students to analyze problems and ideological level of cognition. These articles, the information broke through the boundaries of the ideological and political education in the traditional sense, ideological and political education for college students to provide a strong timeliness, practical significance of the content of education. 


\section{Summary}

The CPC Central Committee and State Council "on further strengthening and improving the ideological and political education of the views" stressed: to take the initiative to occupy the ideological and political education network of new positions. With the development of network technology, the ideological and political education of network has gradually come into people's perspective, and the traditional way of ideological and political education has been supplemented vigorously, and it has become an important part of ideological and political education. The ideological and political education is the new positions. As the most popular mobile social networking platform, the influence of WeChat circle of friends has not been underestimated; it also provides a new channel for college students' ideological and political education. Educators can not only understand the students through the WeChat circle of ideological and dynamic information, you can take the initiative to use WeChat circle of friends to carry out ideological and political education. Friends in the circle to use more illustrations in the form of dissemination of information, educators in such a way to pass on to the students of educational information, will be more intuitive, more image, but also for a time free space constraints platform, the establishment of a high efficiency Information communication mode, but also for teachers and students to build a private interactive space, which makes WeChat circle of friends has become a new ideological and political education of students positions. WeChat circle of friends is an acquaintance relationship-based social circle, with a strong closure and privacy. Survey shows that $76.47 \%$ of college students are willing or do not refuse to add counselors for WeChat friends. From the author's personal experience, because the age gap with the students, many students will take the initiative to add counselors micro letter, and often use WeChat and counselors to communicate, the content of the circle of friends is also open to counselors, counselors can point Like, comments. This exchange of teachers and students changed the traditional way of "I tell you to listen," "I hit you through the" one-way coercion, counselors from the circle of friends found in the student's problems, can be timely grooming and doubts, While counselors can also share their own insights to life circle of friends, so that students participate. WeChat circle of friends to provide teachers and students with equal, interactive and open platform, closer to the distance between teachers and students to promote education and education in the exchange of interaction to create a more equal and harmonious relationship between teachers and students, so that educators in the division Student relationship is more affinity, is conducive to the ideological and political education work carried out smoothly.

\section{References}

[1] Yang Min, WeChat on the ideological and political education of the challenges and coping strategies Yin. Ideological and theoretical education, 2012 (12).

[2] Chen Jun.Micro-letter on the impact of college students interpersonal communication. News World, 2015 (1).

[3] NIE Lei, FU Cui-xiao, CHENG Dan.Micro-letter circle of friends: virtual community in the perspective of social network.News World, 2015 (5).

[4] The Role of WeChat Circles in Internet Rumors. Science and Technology Communication, 2014 C23).

[5] Song Jiangbo.Study on the Influence of Micro-Friend Circle on Interpersonal Communication. Guangxi University, 2014.

[6] Willow, Li Siwei. Micro-marketing phenomenon of micro-faith circle of friends. China media technology, 2014 (6).

[7] Xing Lu.Study on the Ideological and Political Education of College Students under Mobile Media Environment.Journal of Shandong Normal University, 2014. 
[8] The ideological and political education of college students in the era of WeChat color innovation that the school party building and ideological education, 2014 (13). 